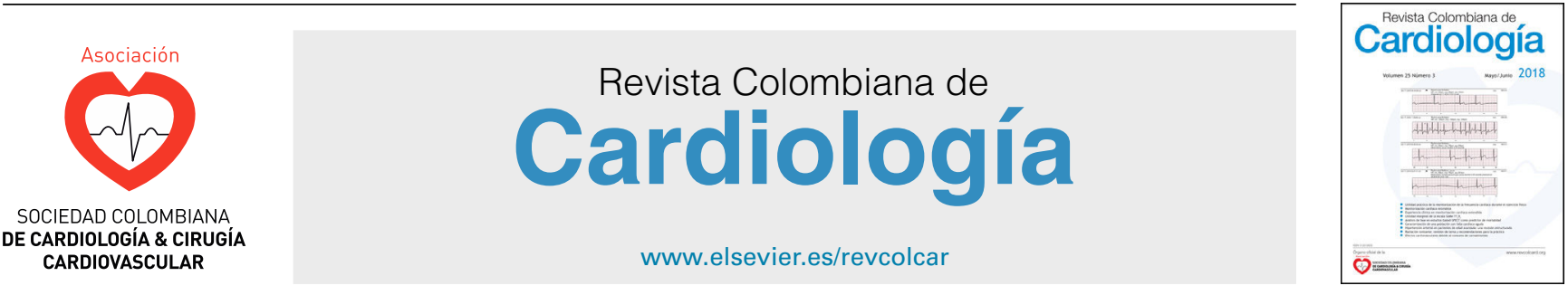

ADULT CARDIOLOGY - ORIGINAL ARTICLES

\title{
Body mass index and coronary revascularization in women with coronary artery disease: insight into obesity paradox
}

\section{Diego Chambergo-Michilot ${ }^{\mathrm{a}, *}$, Fernando M. Runzer-Colmenares ${ }^{\mathrm{a}}$, Ángel Zamora ${ }^{\mathrm{b}}$, Flor Santa-Cruz ${ }^{a}$, Mónica Zamora ${ }^{a}$}

\author{
a Universidad Científica del Sur, Lima, Perú \\ b Centro Médico Naval "Cirujano Mayor Santiago Távara", Callao, Perú
}

Received 5 January 2019; accepted 28 April 2019

Available online 8 July 2019

\section{KEYWORDS \\ Coronary artery \\ disease; \\ Women; \\ Angioplasty; \\ Stent; \\ Peru}

\begin{abstract}
Objective: To determine the association between body mass index and indication of angioplasty with stent implantation in women over 50 years of age.

Material and methods: Retrospective analytical study, cross-sectional. It were evaluated 83 clinical records of women older than 50 years of age who underwent angiography due to coronary artery disease and were hospitalized in Peruvian Naval Medical Center between 2010 and 2017. A Poisson regression analysis was performed to determine the association.

Results: The mean \pm standard deviation of age was $66.51 \pm 8.94$ years. $81.93 \%$ had two or more comorbidities. The frequency of angioplasties with stent implantation was $58 \%$. Body mass index in range of obesity $(45.83 \%)$ was more frequent in patients who received the implant. In the adjusted regression model, overweight patients had lower probability (PR $0.83,95 \% \mathrm{Cl} 0.68$ 0.98 ) to have the indication of implantation as compared to patients with body mass index less than $25 \mathrm{~kg} / \mathrm{m}^{2}$.

Conclusions: Although obesity paradox relationship between body mass index and angioplasty with stent indication has been demonstrated by the multivariate analysis of this study, it is necessary to evaluate obesity with better markers than body mass index before assuming that obesity is a good prognostic factor for coronary artery disease in our patient.

(c) 2019 Sociedad Colombiana de Cardiología y Cirugía Cardiovascular. Published by Elsevier España, S.L.U. This is an open access article under the CC BY-NC-ND license (http:// creativecommons.org/licenses/by-nc-nd/4.0/).
\end{abstract}

\footnotetext{
* Corresponding author.

E-mail address: diegochambergomichilot@hotmail.com (D. Chambergo-Michilot).
} 


\author{
PALABRAS CLAVE \\ Cardiopatía \\ coronaria; \\ Mujeres; \\ Angioplastia; \\ Stent; \\ Perú
}

\section{Índice de masa corporal y revascularización coronaria en mujeres con cardiopatía coronaria: comprensión de la paradoja de la obesidad}

\section{Resumen}

Objetivo: Determinar la asociación entre índice de masa corporal e indicación de angioplastia con implantación de stent en mujeres mayores de 50 años.

Material y métodos: Estudio analítico retrospectivo y transversal. Se evaluaron 83 historias clínicas de mujeres mayores de 50 años, a quienes se les practicó angiografía debido a cardiopatía coronaria y fueron hospitalizadas en el Centro Médico Naval de Perú entre 2010 y 2017. Se realizó un análisis de regresión de Poisson para determinar la asociación.

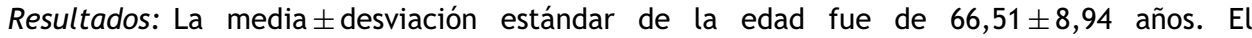
$81,93 \%$ de los casos tenía dos o más comorbilidades. La frecuencia de angioplastias con implantación de stent fue del $58 \%$. El índice de masa corporal en rango de obesidad $(45,83 \%)$ fue más frecuente en las pacientes que recibieron el implante. En el modelo de regresión ajustado, las pacientes con sobrepeso tuvieron menor probabilidad (PR 0,83, 95\% IC 0,68-0,98) de indicación de implantación, en comparación con las pacientes con índice de masa corporal inferior a $25 \mathrm{~kg} / \mathrm{m}^{2}$.

Conclusiones: Aunque la paradoja de la relación de la obesidad entre índice de masa corporal y angioplastia con indicación de stent ha sido demostrada por el análisis multivariante de este estudio, es necesario evaluar la obesidad con mejores marcadores que el índice de masa corporal, antes de asumir que la obesidad es un buen factor pronóstico de cardiopatía coronaria en las pacientes.

( 2019 Sociedad Colombiana de Cardiología y Cirugía Cardiovascular. Publicado por Elsevier España, S.L.U. Este es un artículo Open Access bajo la licencia CC BY-NC-ND (http:// creativecommons.org/licenses/by-nc-nd/4.0/).

\section{Introduction}

Coronary artery disease remains among the most prevalent causes of mortality worldwide. In developing countries, including Latin American countries, an estimated of 19 million deaths is expected by 2020. ${ }^{1}$ This disease progresses over time if it is not treated properly or risk factors are not controlled. Currently, a large percentage of people develops a severe obstruction, being opportune the indication of revascularization with angioplasty or bypass. ${ }^{2}$

It has been demonstrated the advantage of angioplasty with stent implantation over bypass, ${ }^{3,4}$ however, international guidelines suggest patient characteristics that favor the clinical decision for one or another technique. Several authors have studied postoperative cardiac events and mortality, as revascularization leads to considerable surgical risks, nevertheless, there are no studies on risk factors for revascularization indication. Although coronary artery disease is a risk factor per se for its severity, it is necessary to analyze the background and classic cardiovascular risk comorbidities to understand the dynamics of coronary artery disease. One of these factors is the body mass index, ${ }^{5,6}$ which has shown a paradoxical relationship with cardiovascular outcomes, called the "obesity paradox". It consists in the fact that overweight people have equal or lesser burden of causes of mortality, including cardiovascular, than people with normal body mass index. ${ }^{7,8}$ This paradox is represented as a U-shaped or J-shaped curved graphically. There are some solutions to this problems, but, there is no a consensus.
In this context, high body mass index is a predictor for drug therapy indication in male adults only ${ }^{9}$ although cardiovascular risk in women increases after 50 years of age. ${ }^{10}$ However, the association between body mass index and revascularization indication has not been studied. Due to the importance of this knowledge gap, the objective of this study was to determine the association between body mass index and indication of angioplasty with stent implantation in women over 50 years.

\section{Material and methods}

\section{Study design}

This study is a retrospective cross-sectional analysis of a database.

\section{Population and sample}

Study population was made up of medical records of women older than 50 years diagnosed with acute or chronic stable coronary artery disease who underwent a coronary angiography. ${ }^{11}$ The sample size was calculated using the statistical software OpenEpi (https: / /www.openepi.com/) and it resulted in a total of 83 clinical records, using a 95\% confidence interval $(\mathrm{Cl})$.

\section{Selection criteria}

Were included in a non-probabilistic manner the medical records of patients with coronary artery disease who 
underwent angiography and were hospitalized in Peruvian Naval Medical Center "Cirujano Mayor Santiago Távara", (Callao, Peru) between January 2010 and December 2017. The center is a highly complex hospital and national referral health system of the Peruvian Navy. A total of 20 medical records of patients who had incomplete data were excluded.

\section{Description of variables}

Dependent variable. The dependent variable was the angioplasty with second-generation drug-eluting stent implantation in a coronary artery or branch of patients who met the criteria and recommendations for revascularization with this intervention. ${ }^{12}$ The indication of angioplasty was performed after the angiography. Some of coronary artery disease patients did not have diagnosis of chronic stable angina or silent ischemia, however, they showed no invasive tests suggestive of ischemia (stress test, myocardial perfusion or echo-stress), which justified the intervention.

Independent variable. The independent variable was body mass index, which results of the formula "weight $(\mathrm{kg}) /$ height $(\mathrm{m})^{2}$ ". Body mass index was classified in less than $25 \mathrm{~kg} / \mathrm{m}^{2}$, overweight $\left(25-29.9 \mathrm{~kg} / \mathrm{m}^{2}\right)$ and obesity (greater than or equal to $30 \mathrm{~kg} / \mathrm{m}^{2}$ ).

Covariables. Covariables were age, for which the mean \pm standard deviation was calculated, military rank of the holder (subaltern or officer), socioeconomic level of place of residence, it was defined according to the Asociación Peruana de Empresas de Investigación de Mercados, ${ }^{13}$ the levels were limited to high/medium or low/marginal. Number of comorbidities were classified in absence of comorbidities (0), one comorbidity or two or more comorbidities. Comorbidity was defined as the presence of myocardial infarction (MI) history, cardiovascular disease (CVD), excluding coronary artery disease, hypertension, use of neuro-psyquiatric drugs, anxiety, depression, arrhythmias, diabetes mellitus (DM), smoking, heart failure, chronic kidney disease, cerebrovascular disease, venous insufficiency or valvular disease. Other covariables were two scores of 10-year cardiovascular risk. ${ }^{14,15}$ Validated model for populations at high risk of CVD was used for the results of Systematic COronary Risk Evaluation (SCORE) score due to the fact that Peru has been reported as a high risk country for cardiovascular diseases. ${ }^{16}$ Age, smoking and previous hospitalization systolic blood pressure and total cholesterol $(\mathrm{mg} / \mathrm{dl})$ for the SCORE score were recorded. Hhowever, this model was validated only for patients under 65 years of age, therefore a derivative model of SCORE was used, the Systematic COronary Risk Evaluation in Older Persons (SCORE OP) ${ }^{17}$ to evaluate patients over 65 years of age. For the cardiovascular risk measured by Reynolds Risk Score (REYNOLDS), age, smoking, heart attack family history and other values were recorded from the medical record.

\section{Data processing and analysis}

An analysis by the statistical program STATA 14.0 for Windows was performed. Age, comorbidities and SCORE and REYNOLDS scores were expressed as mean \pm standard deviation; the other covariables were expressed as absolute
Table 1 Descriptive analysis and demographic characteristics $(n=83)$.

\begin{tabular}{llll}
\hline Variables & $\mathrm{n}$ & $\%$ & Mean $\pm \mathrm{SD}^{\mathrm{a}}$ \\
\hline $\begin{array}{l}\text { Age }\left(\text { mean } \pm S D^{\mathrm{a}} \text { ) }\right. \\
\text { Military rank }\end{array}$ & & & $66.51 \pm 8.94$ \\
$\quad$ Subaltern & 65 & 78.31 & \\
$\quad$ Officer & 18 & 21.69 & \\
Socioeconomic level & & & \\
$\quad$ High/medium & 29 & 34.94 & \\
$\quad$ Low/marginal & 54 & 65.01 & \\
Comorbidities (mean $\pm S D^{\mathrm{a}}$ ) & & & $2.69 \pm 1.53$ \\
$\quad$ O & 2 & 2.41 & \\
$\quad 1$ & 13 & 15.66 & \\
$\quad 2$ or more & 68 & 81.93 & \\
Body mass index & & & \\
$\quad$ Less than $25 \mathrm{~kg} / \mathrm{m}^{2}$ & 32 & 38.55 & \\
$\quad$ Overweight & 20 & 24.1 & \\
$\quad$ Obese & 31 & 37.35 & \\
SCORE (mean $\pm S D^{\mathrm{a}}$ ) & & & $7.11 \pm 6.23$ \\
REYNOLDS (mean $\pm S D^{\mathrm{a}}$ ) & & & $7.22 \pm 8.63$ \\
\hline a Standard deviation & & & \\
\end{tabular}

counts and percentages. Chi ${ }^{2}$ test was performed to determine the significance of qualitative variables, whereas t-test was performed to determine the significance of continuous variables, a p-value equal or less than 0.05 was considered as a statistically significant result. Finally, Poisson regression model was performed to determine the association between body mass index and stent implantation. It were calculated the prevalence ratios (PR) and $95 \% \mathrm{Cl}$ in a crude and adjusted model for comorbidities, age, SCORE and REYNOLDS scores.

\section{Ethical considerations}

This study is a secondary analysis of the project entitled "Prevalencia del síndrome coronario agudo en pacientes mujeres mayores de 50 años con factores de riesgo cardiovascular atendidas en el Centro médico naval en los últimos veinte años" which was evaluated and approved by the Research Ethics Committee of Peruvian Naval Medical Center. Data processing did not include any aspect of patients' identity; they were recognized by codes.

\section{Results}

It were evaluated 83 medical records of female patients over 50 years of age who underwent an angiography and were hospitalized at the medical center, being $58 \%$ the percentage of angioplasties with stent implantation.

Table 1 presents demographic characteristics. To begin, the mean \pm standard deviation of age was $66.51 \pm 8.94$ years. $65.01 \%$ of patients came from a district of low/marginal socioeconomic level. $81.93 \%$ had two or more comorbidities. $37.35 \%$ were obese according to body mass index. Additionally, the mean \pm standard deviation of SCORE and REYNOLDS were $7.11 \pm 6.23 \%$ and $7.22 \pm 8.63 \%$ respectively. 
Table 2 Bivariate analysis for stent implantation $(n=83)$.

\begin{tabular}{|c|c|c|c|}
\hline \multirow[t]{2}{*}{ Variables } & \multicolumn{2}{|c|}{ Stent implantation } & \multirow[t]{2}{*}{ P-value } \\
\hline & No $n=35(42 \%)$ & Yes $n=48(58 \%)$ & \\
\hline Age $\left(\right.$ mean $\left.\pm S D^{\mathrm{a}}\right)$ & $66.89 \pm 8.54$ & $66.23 \pm 9.3$ & 0.743 \\
\hline Military rank & & & 0.825 \\
\hline Subaltern & $27(77.14)$ & $38(79.17)$ & \\
\hline Officer & $8(22.86)$ & $10(20.83)$ & \\
\hline Body mass index & & & 0.147 \\
\hline Less than $25 \mathrm{~kg} / \mathrm{m}^{2}$ & $17(48.57)$ & $15(31.25)$ & \\
\hline Overweight & $9(25.71)$ & $11(22.92)$ & \\
\hline Obese & $9(25.71)$ & $22(45.83)$ & \\
\hline Comorbidities (mean $\pm S D^{\mathrm{a}}$ ) & $2.97 \pm 1.69$ & $2.48 \pm 1.38$ & 0.148 \\
\hline $\operatorname{SCORE}\left(\right.$ mean $\left.\pm S D^{\mathrm{a}}\right)$ & $7.91 \pm 7.11$ & $6.51 \pm 5.48$ & 0.315 \\
\hline REYNOLDS (mean $\pm S D^{\mathrm{a}}$ ) & $9.77 \pm 11.66$ & $5.35 \pm 4.8$ & 0.02 \\
\hline
\end{tabular}

a Standard deviation

Table 3 Poisson regression to determine the association between body mass index and stent implantation $(n=83)$.

\begin{tabular}{|c|c|c|}
\hline Variables & Crude model PR (Cl 95\%) & Adjusted model PR $(\mathrm{Cl} 95 \%)^{\mathrm{b}}$ \\
\hline \multicolumn{3}{|l|}{ Body mass index } \\
\hline Less than $25 \mathrm{~kg} / \mathrm{m}^{2}$ & Reference & Reference \\
\hline Overweight & $0.86(0.77-0.95)$ & $0.83(0.68-0.98)$ \\
\hline Obese & $2.77(0.98-7.85)$ & $1.51(1.02-2.33)$ \\
\hline
\end{tabular}

Table 2 presents variables paired with stent implantation. Body mass index less than $25 \mathrm{~kg} / \mathrm{m}^{2}$ (48.57\%), comorbidities $(2.97 \pm 1.69)$, SCORE $(7.91 \pm 7.11)$ and REYNOLDS $(9.77 \pm 11.66)$ were predominant in patients who did not receive the intervention, while body mass index in range of obesity $(45.83 \%)$ was more frequent in patients who received the implant.

In Table 3 the Poisson regression model is presented. In the adjusted model for comorbidities, age, SCORE and REYNOLDS, overweight patients had lower probability (PR $0.83,95 \% \mathrm{Cl} 0.68-0.98$ ) to have the indication of implantation as compared to patients with body mass index less than $25 \mathrm{~kg} / \mathrm{m}^{2}$. Moreover, obese patients were more likely (PR $1.51,95 \% \mathrm{Cl} 1.02-2.33$ ) to have the indication, compared with body mass index less than $25 \mathrm{~kg} / \mathrm{m}^{2}$.

In Figure 1 a bar chart depicting the frequency of stent implantations according to body mass index is presented. Among patients who received the implantation, $31.25 \%$ had body mass index less than $25 \mathrm{~kg} / \mathrm{m}^{2}, 22.92 \%$ were overweight, and $45.83 \%$ were obese, this was plotted as a U-shaped curve.

\section{Discussion}

This study aimed to determine the association between body mass index and angioplasty with stent implantation indication in patients with coronary artery disease. In the adjusted model it was found that obese women had a $51 \%$ higher probability to have the indication compared to patients with body mass index lower than $25 \mathrm{~kg} / \mathrm{m}^{2}$.
Obesity is a chronic disease that leads to a molecularly endocrine homeostasis disorder due to decrease of adiponectin and increase of leptin and other inflammatory cytokines which not only affect the endothelial function but insulin sensitivity and weight gain, ${ }^{18-20}$ being even a risk factor for early development of coronary artery disease. ${ }^{21}$ There are several adiposity markers, the most used are the waist-to-hip ratio, waist circumference and body mass index. High body mass index is a cardiovascular risk factor in women ${ }^{22}$ and men, ${ }^{6}$ however, diseases do not have a static evolution, but it progresses when adequate control is not achieved. For coronary artery disease, progressivity depends on the functionality and anatomy of the affected heart arteries, the amount of affected vessels and the degree of obstruction are important characteristics. While pharmacological treatment is efficient for coronary artery disease, when obstruction is severe or multi-vessel, revascularization treatment shows considerable benefits. ${ }^{3}$ Additionally, it has become apparent that the complexity of coronary artery disease, as measured by validated scores, such as SYNTAX, ${ }^{23}$ is a predictor of revascularization prediction ${ }^{2}$ and it is associated with mortality. ${ }^{24}$ Widlansky et al. ${ }^{25}$ analyzed a cohort follow-up of 5010 patients with coronary artery disease and cerebrovascular disease or MI history, concluding that body mass index did not correlate strongly with increased risk of cardiovascular mortality, it may be due to comorbidities and lack of adjustment for coronary artery disease severity or complexity, this fact might be intervening in the association. Furthermore, Labounty et al. ${ }^{26}$ analyzed medical records of 13874 people from Europe, America and Asia countries, 


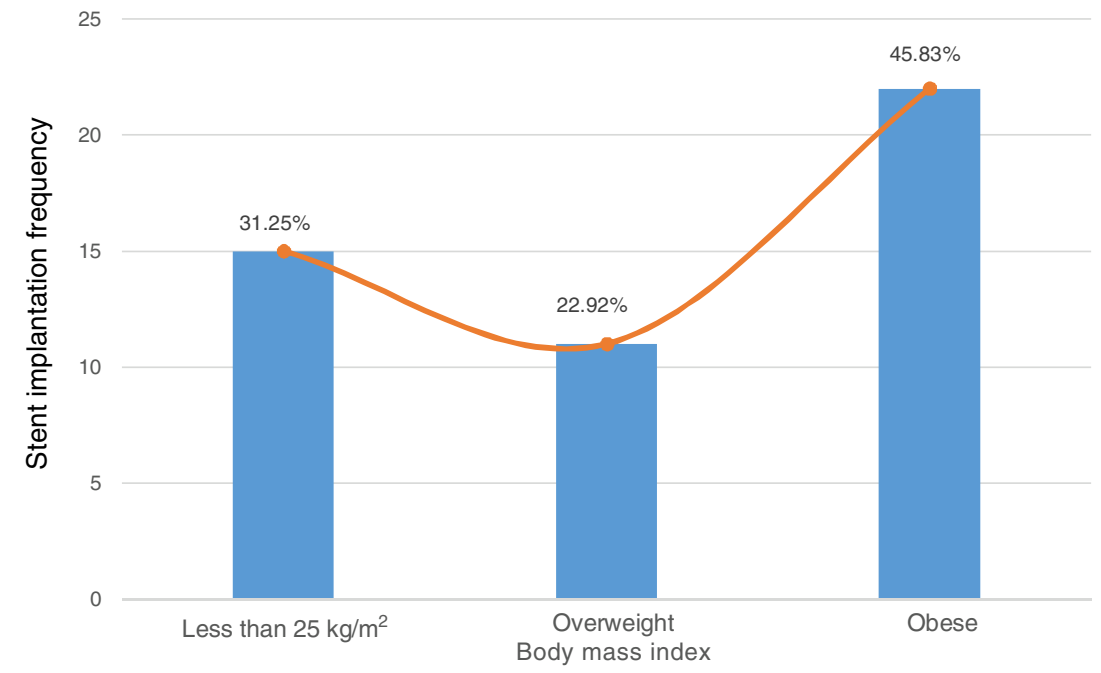

Figure 1 Bar chart and U-shaped curve in the body mass index and stent implantation association.

they concluded that high body mass index is an independent risk factor of coronary artery disease severity. Wang et al. ${ }^{27}$ meta-analyzed primary studies which were published from 1980 to 2014 , concluding that body mass index is directly proportional to repeat revascularization in patient with a first angioplasty. Our study is consistent with the message of the background, nevertheless, it should be aware that Peru is a country with low cardiovascular health, ${ }^{16}$ so this could be skewing the interpretation for our study.

Despite the evidence, there is a phenomenon which has been often reported by systematic reviews and observational studies, as well as the present study, called the obesity paradox. Currently, the dispute between overweight and its implications on health has increased because several studies have reported that all-causes of mortality are similar or lower in people with body mass index in overweight range compared to people with normal body mass index. ${ }^{7}$ A meta-analysis of 89 primary studies, with approximately 1.3 million participants, concluded that people with coronary artery disease and high body mass index have lower mortality compared with people with normal body mass index, showing a J-shaped curve graphically. ${ }^{28}$ Because of heterogeneity $\left(I^{2} 77.6 \%\right)$ of the primary studies, a random effects model to assess mortality of people with coronary artery disease and overweight compared to people with normal weight was included, the average effect (random: RR $0.82,95 \% \mathrm{Cl} 0.78-0.86$ ) was protector. Ueshima et al. ${ }^{29}$ analyzed medical records of 1684 patients receiving a drug-eluting stent, noting that people with body mass index in overweight range had lower mortality than people with normal body mass index. In our study, an association between body mass index and stent implantation was observed and graphed as a U-shaped curve (fig. 1). Several studies have observed the U-shaped or J-shaped curves in the association between body mass index and cardiovascular outcomes, such as mortality, ${ }^{30}$ however, this paradox has several hypotheses of response. An analysis of 10 cohorts in US, with a total population of 190 672, found that people with body mass index in overweight and obese ranges had higher survival with diagnosed CVD than people with normal body mass index, suggesting that early diagnosis would be causing the paradox. ${ }^{7}$ Probably it is due to the fact that people with higher body mass index were young at the moment of being diagnosed, so their organ systems were better able to withstand the CVD evolution. Moreover, Romero-Corral et al. ${ }^{31}$ meta-analyzed 40 primary studies whose population were patients with coronary artery disease, concluding that patients with body mass index in overweight and obese ranges had lower mortality risk than patients with normal body mass index, justifying the fact that body mass index does not have enough power to discriminate between fat and mass. From an anatomical point of view, Akin and Nienaber ${ }^{32}$ proposed that patients with high body mass index have longer coronary arteries than patients with normal body mass index, being a good prognostic factor for coronary artery disease evolution. Although it is a coherent solution for the paradox, this must be extrapolated in all population for validity. Another explanation is that in the studies that showed this pattern of association it has not been taken into account the protective factor or other diseases that could alter the results, however, a study which controlled these factors showed the same curve, so this explanation cannot be applied to all cases. Allison et al. ${ }^{33}$ suggested that the paradox can be explained by the poor conception of body mass index, it is misinterpreted as a pure measure of adiposity, which could be generating a gap in the real understanding of the association between high body mass index and CVD. This hypothesis is based around the concept of one component of the body mass index equation, the mass. This term does not refer exclusively to body fat, which has harmful effects on health, but fat-free mass, which has beneficial effects on health. Meta-analysis and observational studies have found that central obesity measures, such as weightto-height and waist-to-hip ratios, are better cardiovascular risk and coronary artery disease severity markers than body mass index. ${ }^{34,35}$ In addition, a prospective study of patients with suspected coronary artery disease showed positive correlation between waist-to-hip ratio and coronary artery disease severity, also noted the paradox between body mass index and severity. ${ }^{36}$ This evidence is consistent with the 
proposal that body mass index fails to discriminate true obese people.

In our study, women older than 50 years were evaluated, so they were menopausal or already went through it. Menopause begins between 45 and 55 years of age and produces a dramatic decrease of progesterone and estrogen, the latter being a cardioprotect hormone, so the incidence of CVD increases. ${ }^{37}$ It has been observed that menopausal women are at higher risk of abdominal obesity than premenopausal women, contributing to insulin resistance and hypertension. ${ }^{38}$ This fact means that the isolated obesity has no causality association with CVD in most cases, but predisposes to suffer from comorbidities that together explain the onset of the disease, which is why multi-comorbid coronary artery disease patients are often attended in clinical practice. Some classic comorbidities that are not only added diseases but cardiovascular risk factors are MI history, CVD family history, hypertension, smoking and DM. Other studies have found that anxiety, depression, heart failure and arrhythmias are important cardiovascular risk factors. ${ }^{39,40}$ The relationship between comorbidities and coronary artery disease has been clarifies in the last decade. There is a synergy between DM and obesity in the pathophysiologic mechanism of coronary artery disease. ${ }^{41}$ Also several authors have explored the relationship between coronary artery disease and comorbidities in large populations. Alkhawam et al ${ }^{42}$ analyzed a population with coronary artery disease and high body mass index, concluding that smoking, hyperlipidemia, DM and hypertension are risk factors for coronary artery disease severity, however, although it is a crosssectional study, odds ratios were high and significant. Rea et al ${ }^{43}$ analyzed a cohort of people with MI history, concluding that high body mass index was associated with risk of coronary events, however, DM, hypertension and dyslipidemia explained the association, since the risk of obese increased proportionally to the amount of comorbidities. Although in our study the statistical significance of the number of comorbidities between groups (received or not the stent implantation) was not significant $(p=0.148)$, this variable does not discriminate each comorbidity, only grouped in quantity.

The main limitation is that the sample comes from families of workers from the Peruvian Navy, so the results cannot be extrapolated to the national population of women over 50 years of age, and as it is a hospital population, there is a selection bias. DM history and other variables were collected by review of medical records, so there is self-reporting bias. This study did not aim to know if the group who had no indication of angioplasty had bypass indication, besides the medical center does not perform metal stent implantation, so it was not possible to conduct a subgroup analysis, however, because of the fact that drugeluting stent is the most widely used of stents, ${ }^{29}$ results are applicable for other users. Moreover, the time of evolution of the comorbidities was not obtained, therefore it could affect the analysis. Despite these limitations, this study contributes to the secondary prevention of coronary artery disease in women, in addition, we recommend to take into account that body mass index is not the best predictor of cardiovascular risk, so it is preferable to evaluate the patients with other markers that have demonstrated superiority over body mass index, such as abdominal circumference and waist-to-hip ratio, ${ }^{44}$ before concluding that obesity is not a risk factor for coronary artery disease severity. Finally, new studies about cardiovascular risk factors in primary health care are recommended.

\section{Conclusions}

Although obesity paradox relationship between body mass index and angioplasty with stent indication has been demonstrated by the multivariate analysis of this study, it is necessary to evaluate obesity with better markers than body mass index before assuming that obesity is a good prognostic factor for coronary artery disease in our patients.

\section{Authorship}

Diego Chambergo-Michilot: conception, design, data recollection, data interpretation, critical revision and final approval

Fernando M. Runzer-Colmenares: conception, design, analysis, data interpretation, critical revision, final approval

Ángel Zamora: design, data interpretation, critical revision, final approval

Flor Santa-Cruz: conception, data interpretation, critical revision, final approval

Mónica Zamora: conception, data interpretation, critical revision, final approval

\section{Funding}

Self-financed.

\section{Conflict of interests}

None.

\section{Acknowledgment}

To Mrs. Maria Campos, who supported us and encouraged us.

\section{References}

1. Sanchis-Gomar F, Perez-Quilis C, Leischik R, Lucia A. Epidemiology of coronary heart disease and acute coronary syndrome. Ann Transl Med. 2016;4:256.

2. Fink N, Nikolsky E, Assali A, Shapira O, Kassif Y, Barac YD, et al. Revascularization strategies and survival in patients with multivessel coronary artery disease. Ann Thorac Surg. 2019;107:106-11.

3. Patel MR, Calhoon JH, Dehmer GJ, Grantham JA, Maddox TM, Maron DJ, et al. ACC/AATS/AHA/ASE/ASNC/SCAI/SCCT/STS 2017 Appropriate Use Criteria for Coronary Revascularization in Patients With Stable Ischemic Heart Disease: A Report of the American College of Cardiology Appropriate Use Criteria Task Force, American Association for Thoracic Surgery, American Heart Association, American Society of Echocardiography, American Society of Nuclear Cardiology, Society for Cardiovascular Angiography and Interventions Society of Cardiovascular Computed Tomography, and Society of Thoracic Surgeons. J Nucl Cardiol. 2017;24:1759-92. 
4. Bangalore S, Guo Y, Samadashvili Z, Blecker S, Hannan EL. Revascularization in patients with multivessel coronary artery disease and severe left ventricular systolic dysfunction: everolimus-eluting stents versus coronary artery bypass graft surgery. Circulation. 2016;133:2132-40.

5. Global Burden of Cardiovascular Diseases C. The burden of cardiovascular diseases among us states, 1990-2016. JAMA Cardiology. 2018;3:375-89.

6. Bangalore S, Fayyad R, Laskey R, DeMicco DA, Messerli FH, Waters DD. Body-Weight Fluctuations and Outcomes in Coronary Disease. N Eng J Med. 2017;376:1332-40.

7. Khan SS, Ning H, Wilkins JT, et al. Association of body mass index with lifetime risk of cardiovascular disease and compression of morbidity. JAMA Cardiology. 2018;3:280-7.

8. Lavie CJ, De Schutter A, Parto P, Jahangir E, Kokkinos P, Ortega FB, et al. Obesity and prevalence of cardiovascular diseases and prognosis-the obesity paradox updated. Progress in Cardiovascular Diseases. 2016;58:537-47.

9. Vogel B, Farhan S, Hahne S, Kozanli I, Kalla K, Freynhofer MK, et al. Sex-related differences in baseline characteristics, management and outcome in patients with acute coronary syndrome without ST-segment elevation. Eur Heart J: Acute Cardiovascular Care. 2015;5:347-53.

10. Garcia M, Mulvagh SL, Merz CNB, Buring JE, Manson JE. Cardiovascular disease in women: clinical perspectives. Circulation Research. 2016;118:1273-93.

11. Fihn SD, Blankenship JC, Alexander KP, Bittl JA, Byrne JG, Fletcher BJ, et al. 2014 ACC/AHA/AATS/PCNA/SCAI/STS focused update of the guideline for the diagnosis and management of patients with stable ischemic heart disease: a report of the American College of Cardiology/American Heart Association Task Force on Practice Guidelines, and the American Association for Thoracic Surgery Preventive Cardiovascular Nurses Association, Society for Cardiovascular Angiography and Interventions, and Society of Thoracic Surgeons. J Am Coll Cardiol. 2014;64:1929-49.

12. Neumann F-J, Sousa-Uva M, Ahlsson A, Alfonso F, Banning AP, Benedetto U, et al. 2018 ESC/EACTS Guidelines on myocardial revascularization. Eur Heart J. 2018, ehy394-ehy.

13. Mercado APdEdld. Niveles socioeconómicos en Lima Metropolitana y Callao. Asociación Peruana de Empresas de Investigación de Mercado Lima. 2005.

14. Conroy R. Estimation of ten-year risk of fatal cardiovascular disease in Europe: the SCORE project. Eur Heart J. 2003;24:987-1003.

15. Ridker P, Buring JE, Rifai N, Cook NR. Development and validation of improved algorithms for the assessment of global cardiovascular risk in women: The Reynolds risk score. JAMA. 2007; 297:611-9.

16. Benziger CP, Zavala-Loayza JA, Bernabe-Ortiz A, Gilman RH, Checkley W, Smeeth L, et al. Low prevalence of ideal cardiovascular health in Peru. Heart. 2018;104:1251-6.

17. Cooney MT, Selmer R, Lindman A, Tverdal A, Menotti A, Thomsen $\mathrm{T}$, et al. Cardiovascular risk estimation in older persons: SCORE O.P. European Journal of Preventive Cardiology. 2015;23:1093-103.

18. Bagi Z, Broskova Z, Feher A. Obesity and coronary microvascular disease - implications for adipose tissue-mediated remote inflammatory response. Current Vascular Pharmacology. 2014; 12:453-61.

19. Apostolopoulos V, de Courten MP, Stojanovska L, Blatch GL, Tangalakis $\mathrm{K}$, de Courten $\mathrm{B}$. The complex immunological and inflammatory network of adipose tissue in obesity. Mol Nutr Food Res. 2016;60:43-57.

20. Ne JYA, Cai TY, Celermajer DS, Caterson ID, Gill T, Lee CMY, et al. Obesity, arterial function and arterial structure - a systematic review and meta-analysis. Obes Sci Pract. 2017;3: $171-84$.
21. Dhana K, Berghout MA, Peeters A, Ikram MA, Tiemeier H, Hofman $A$, et al. Obesity in older adults and life expectancy with and without cardiovascular disease. Int J Obes (Lond). 2016;40:1535-40.

22. Barroso M, Goday A, Ramos R, Marin-Ibanez A, Guembe MJ, Rigo $\mathrm{F}$, et al. Interaction between cardiovascular risk factors and body mass index and 10-year incidence of cardiovascular disease, cancer death, and overall mortality. Prev Med. 2018;107:81-9.

23. Yammine M, Itagaki S, Pawale A, Toyoda N, Reddy RC. SYNTAX score may predict the severity of atherosclerosis of the ascending aorta. J Thorac Dis. 2017;9:3859-65.

24. Franzone A, Taniwaki M, Rigamonti F, Heg D, Piccolo R, Roffi $M$, et al. Angiographic complexity of coronary artery disease according to SYNTAX score and clinical outcomes after revascularisation with newer-generation drug-eluting stents: a substudy of the BIOSCIENCE trial. Eurolntervention. 2016;12:e595-604.

25. Widlansky ME, Sesso HD, Rexrode KM, Manson JE, Gaziano J. Body mass index and total and cardiovascular mortality in men with a history of cardiovascular disease. Arch Int Med. 2004; 164:2326-32.

26. Labounty TM, Gomez MJ, Achenbach S, Al-Mallah M, Berman DS, Budoff MJ, et al. Body mass index and the prevalence, severity, and risk of coronary artery disease: an international multicentre study of 13,874 patients. Eur Heart J Cardiovasc Imaging. 2013;14:456-63.

27. Wang ZJ, Gao F, Cheng WJ, Yang Q, Zhou YJ. Body Mass Index and Repeat Revascularization After Percutaneous Coronary Intervention: A Meta-analysis. Can J Cardiol. 2015;31:800-8.

28. Wang ZJ, Zhou YJ, Galper BZ, Gao F, Yeh RW, Mauri L. Association of body mass index with mortality and cardiovascular events for patients with coronary artery disease: a systematic review and meta-analysis. Heart. 2015;101:1631-8.

29. Ueshima D, Yoshikawa S, Sasaoka T, Hatano Y, Kurihara K, Maejima $Y$, et al. Obesity paradox in the era of percutaneous coronary intervention with 2 nd-generation drug-eluting stents: an analysis of a multicenter PCI registry. Heart Vessels. 2018.

30. Canoy D, Cairns BJ, Balkwill A, Wright FL, Green J, Reeves G, et al. Body mass index and incident coronary heart disease in women: a population-based prospective study. BMC Medicine. 2013;11:87-90.

31. Romero-Corral A, Montori VM, Somers VK, Korinek J, Thomas RJ, Allison TG, et al. Association of bodyweight with total mortality and with cardiovascular events in coronary artery disease: a systematic review of cohort studies. The Lancet. 2006;368:666-78.

32. Akin I, Nienaber CA. Obesity paradox"' in coronary artery disease. World J Cardiol. 2015;7:603-8.

33. Allison DB, Faith MS, Heo M, Kotler DP. Hypothesis concerning the U-shaped relation between body mass index and mortality. Am J Epidemiol. 1997;146:339-49.

34. Lee CMY, Huxley RR, Wildman RP, Woodward M. Indices of abdominal obesity are better discriminators of cardiovascular risk factors than body mass index: a meta-analysis. J Clin Epidemiol. 2008;61:646-53.

35. Sabah KMN, Chowdhury AW, Khan HLR, Hasan AH, Haque S, Ali $\mathrm{S}$, et al. Body mass index and waist/height ratio for prediction of severity of coronary artery disease. BMC research notes. 2014;7:246.

36. Parsa AF, Jahanshahi B. Is the relationship of body mass index to severity of coronary artery disease different from that of waistto-hip ratio and severity of coronary artery disease? Paradoxical findings. Cardiovasc J Afr. 2015;26:13-6.

37. Appelman Y, van Rijn BB, Monique E, Boersma E, Peters SA. Sex differences in cardiovascular risk factors and disease prevention. Atherosclerosis. 2015;241:211-8.

38. Miguel-Soca PE, Rivas-Estévez M, Sarmiento-Teruel Y, MariñoSoler AL, Marrero-Hidalgo M, Mosqueda-Batista L. Factores de 
riesgo de enfermedad cardiovascular en mujeres con menopausia. Rev Fed Arg Cardiol. 2014;43:90-6.

39. Kendir C, van den Akker M, Vos R, Metsemakers J. Cardiovascular disease patients have increased risk for comorbidity: A crosssectional study in the Netherlands. European Journal of General Practice. 2018;24:45-50.

40. Tušek-Bunc K, Petek D. Comorbidities and characteristics of coronary heart disease patients: their impact on health-related quality of life. Health and quality of life outcomes. 2016; 14:159.

41. Strissel KJ, Denis GV, Nikolajczyk BS. Immune regulators of inflammation in obesity-associated type 2 diabetes and coronary artery disease. Current Opinion in Endocrinology, Diabetes, and Obesity. 2014;21:330.
42. Alkhawam H, Nguyen J, Sayanlar J, Sogomonian R, Desai R, Jolly $\mathrm{J}$, et al. Coronary artery disease in patients with body mass index $>/=30 \mathrm{~kg} / \mathrm{m}(2)$ : a retrospective chart analysis. J Community Hosp Intern Med Perspect. 2016;6:31483.

43. Rea TD, Heckbert SR, Kaplan RC, Psaty BM, Smith NL, Lemaitre $\mathrm{RN}$, et al. Body mass index and the risk of recurrent coronary events following acute myocardial infarction. Am J Cardiol. 2001;88:467-72.

44. Czernichow S, Kengne AP, Stamatakis E, Hamer M, Batty GD. Body mass index, waist circumference and waist-hip ratio: which is the better discriminator of cardiovascular disease mortality risk?: evidence from an individual-participant metaanalysis of 82864 participants from nine cohort studies. Obes Rev. 2011;12:680-7. 